\title{
IZGUDROTĀJDARBĪBAS ATTĪSTĪBA LATVIJĀ: IZGUDROTĀJU BIEDRĪBAS, IZSTĀDES, PATENTI UN RACIONALIZATORU KUSTĪBA
}

IVANS GRIN̦EVIČS*

Latvijas Zinātṇu vēstures asociācija

Kopsavilkums. Raksts iepazīstina ar izgudrotājdarbību un izgudrotāju biedrībām Latvijā no cariskās Krievijas laika 18. gadsimtā līdz 2019. gadam. Par izgudrotājdarbību līdz šim apkopojoša pētījuma nav, ir pētījums tikai par starpkaru laiku. Izgudrotāju vidū ir daudz inženieru, un šajā pētījumā atspoguḷota Rīgas Politehnikuma (RP), Rīgas Politehniskā institūta (RPI) un Rīgas Tehniskās universitātes (RTU) studentu, absolventu un mācībspēku līdzdalība izgudrotājdarbībā. Pētījumā sniegts ieskats izgudrojumu aizsardzības vēsturē, izgudrotājdarbībā, starptautiskajās izgudrojumu un inovāciju izstādēs, izgudrotāju biedrību darbā.

Atslēgas vārdi: izgudrojumu izstādes, izgudrotāju biedrības, Rīgas Politehniskais institūts, Rīgas Tehniskā universitāte.

\section{Ievads}

Zinātniski tehnisko izgudrojumu vēsture un to tiesību aizsardzība iestiepjas dziḷi pagātnē. Tagadējās Latvijas teritorijā izgudrojumu aizsardzība sākās 18. gadsimtā, kad Latvija bija cariskās Krievijas sastāvā un izgudrojumus aizsargāja privilēǵija (patenta nosaukums Krievijā līdz 1917. gadam). Nodibinoties Latvijas Republikai, izgudrojumu autorību un autora tiesības uz izgudrojumu aizsargāja juridisks dokuments patents. Pēc Otrā pasaules kara, kad Latvija bija Padomju Sociālistisko Republiku Savienības (PSRS) sastāvā, populāra bija ne tikai izgudrotājdarbība, bet arī racionalizatoru kustība.

* Korespondējošais autors.

E-pasts: biedriba_inflanty@inbox.lv

(C) 2020 Ivans Griṇevičs. Izdevējs RTU Izdevniecība.

Raksts publicēts brīvpieejā saskañā ar Creative Commons licenci CC BY 4.0.

(https://creativecommons.org/licenses/by/4.0/). 
Izgudrojums var būt saistīts ar kādu ierīci, paṇēmienu, vielu vai biologisko materiālu. Izgudrojums ir kādas problēmas tehniskais risinājums jaunrades rezultātā, kas atškiras no jau esošajiem risinājumiem un kam ir kāds pozitīvs efekts, praktisks lietojums. No milzīgā izgudrojuma klāsta tikai nedaudzi tiek reǵistrēti, vēl mazāk - ieviesti ražošanā.

Latvijas Republikā reǵistrētos izgudrojumus jau 100 gadu aizsargā patenti. Lai cīnītos par savām tiesībām un kopīgi risinātu gan dažādas problēmas, gan popularizētu izgudrotājdarbību, tika dibinātas izgudrotāju biedrības, kas Latvijā darbojas jau gandrīz simts gadu.

Raksta mērḳis ir sniegt vispusīgu ieskatu izgudrotājdarbībā Latvijā kopš 19. gadsimta, izceḷot nozīmīgākos notikumus un svarīgākos lēmumus, kā arī atklāt RP, RPI un RTU studentu, absolventu un mācībspēku devumu izgudrotājdarbībā.

\section{Patentēšanas pirmsākumi cariskajā Krievijā}

Līdz brīdim, kad radās neatkarīga Latvijas valsts, izgudrotāju darbību tagadējās Latvijas teritorijā aizsargāja cariskās Krievijas likumdošana. Krievijā līdz pat 1917. gada revolūcijai izgudrojumus aizsargāja privilēǵija.

Privilēǵija bija pirmtiesības ražot un lietot. Privilēǵijas tika izsniegtas cilvēkiem, kas kaut ko izgudroja. Krievijā tās sāka izsniegt no 18. gadsimta vidus. Pirmo privilēǵiju 1748. gada 2. martā saṇēma tirgotāji Antons Tavlevs (Антон Тавлев; ?-?), Terentijs Voloskovs (Терентий Волосков; 1729-1806) un Ivans Dedovs (Иван Дедов; ?-?) fabriku būvniecībai, lai ražotu krāsas pēc viṇu ieteiktās metodes. Līdz 1812. gadam bija izsniegtas 76 privilēǵijas ražošanā, tirdzniecībā un izgudrojumos amatniecībā un mākslās. 1812. gada 17. jūnijā tika parakstīts manifests «Par privilēgijām uz dažādiem izgudrojumiem un atklājumiem amatniecībā un mākslās», 10. decembrī tika izdots Iekšlietu ministrijas ukazs (Krievijā: monarha, arī augstas varas iestādes lēmums, rīkojums, kam bija likuma spēks) par privilēǵijas izsniegšanu Amerikas Savienoto Valstu Nujorkas pilsētas iedzīvotājam Robertam Fultonam (Robert Fulton; 1765-1815) par Krievijā izgudrotā ar tvaiku darbināmā gaisa kuǵa uzstādīšanu un izmantošanu. Tā bija pirmā reize, kad privilēǵijas piešksīra saskaṇā ar 1812. gada manifestu. 1833. gada 22. novembrī klajā nāca «Privilēǵiju nolikums», kurā bija izvirzītas augstas prasības pret izgudrojumiem un to izskatǐšanu $[1,2]$.

1870. gadā Krievijā tika izdots jauns ukazs «Par izmaiṇām privilēǵiju uz jaunu atklājumu un izgudrojumu izsniegšanas kārtības lietvedībā». Ja iesniegums atbilda ukaza noteikumiem, valsts iestādēm bija jāizsniedz privilēǵija. Privilēǵiju izsniegšanas dokumentos cariskajā Krievijā 
atrodami gan Krievijas, gan ārvalstu izgudrotāju vārdi. No 1813. līdz 1917. gadam tika izsniegtas 36079 privilēgijas: 29730 (82,4 \%) ārzemju izgudrotājiem un 6349 (17,6 \%) - Krievijas izgudrotājiem [1, 2]. Pēdējais tiesībakts attiecībā uz izgudrojumiem cariskajā Krievijā tika pieṇemts 1896. gadā - «Nolikums par izgudrojuma un pilnveidošanas privilēgijām» ar papildinājumiem 1900. un 1912. gadā. Krievijā darbojās Tehnisko lietu komiteja (1896-1918), kas izskatīja iesniegumus un izsniedza privilēgijas. Šajā komitejā par privilēgiju un izgudrojumu lietu ekspertu strādājis RP absolvents (1889), Tomskas Tehnologiskā institūta profesors Jozefs Rončevskis (Рончевский Иосиф Игнатьевич; 1864-1921) [3].

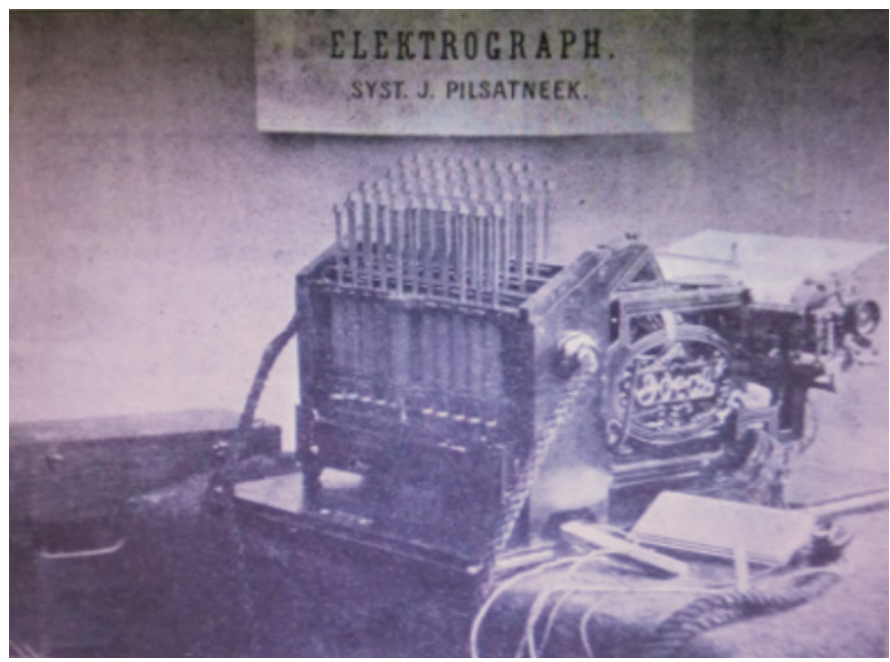

1. attēls. RPI Inženieru nodalas studenta Jēkaba Pilsātnieka konstruētais elektrogrāfs (20. gadsimta sākums).

Izgudrotājdarbībā iesaistījās arī RP/RPI studenti un mācībspēki. Piemēram, Jēkabs Pilsātnieks (1880-1946), kurš studēja Rīgas Politehniskā institūta Inženieru nodaḷā (1899-1913), jau pirmajos studiju gados konstruēja elektrogrāfu un tā darbību un priekšrocības aprakstīja Rīgas Tehniskās biedrības laikrakstā «Rigasche Industrie-Zeitung» [4].

\section{Patentēšanas pirmsākumi un izgudrotājdarbība Latvijas Republikā starpkaru laikā}

Iegūstot valstisko neatkarību, Latvija izveidoja savu izgudrojumu aizsardzības sistēmu un autora tiesību uz izgudrojumu atzīšanai, līdzīgi kā citās valstīs ieviesa patentus - juridiskus dokumentus, kas apliecināja izgudrojumu autorību un autortiesības. Pirmās darbības rūpnieciskā īpašuma aizsardzības jomā Latvijas Republikā sākās 1919. gada otrajā pusē ar likumprojekta par izgudrojumu patentu un preču zīmju izstrādi. Šajā 
laikā tika saṇemti pirmie patentu pieteikumi un preču zīmju pieprasījumi, kuru izskatīšana vēl nevarēja notikt, jo nebija apstiprināts likums par patentiem.

1920. gada 5. februārī ar tirdzniecības un rūpniecības ministra rīkojumu tika iecelta Patentu valde, kas sāka darboties pēc četrām dienām Finanšu ministrijas Rūpniecības departamenta paspārnē. Patentu valdi kopš tās pastāvēšanas pirmajām dienām 1920. gadā līdz tās slēgšanai 1940. gadā vadīja inženieris Jānis Purics (1880-1954) [5; 19. lpp.].

Patentu valdē bija Patentu komiteja, kas izskatīja patentu pieteikumus un lēma par patentu piešksiršanu. Latvijas Republika par pamatu rūpnieciskā īpašuma aizsardzības tiesiskās bāzes veidošanai izmantoja cariskās Krievijas 1913. gada Rūpniecības nolikuma otro dalı, kas, sākot no 69. panta, ietver patentu likumus. Virkne minētā nolikuma pantu tika piemēroti vietējiem apstākḷiem. 1919. gada 16. jūlijā likuma kārtībā tika izdoti «Pārgrozījumi noteikumos par izgudrojumu, modeḷu un preču nozīmju aizsardzības apliecību un patentu izdošanas kārtību», kas apstiprināti 1921. gada 22. decembrī. Pēc tam varēja sākties izskatīto izgudrojumu patentu izsniegšana [6].

2. attēls. Izgudrotājs Andrejs Golvers (1868-1946) (1919).

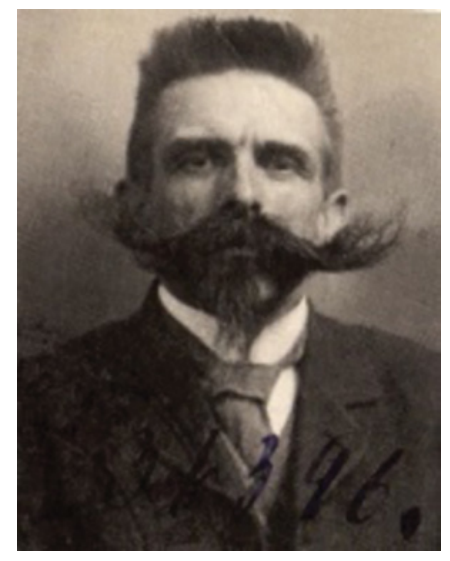

Izgudrojumiem, kas tika pieteikti patentēšanai, pirms patenta piešķiršanas izsniedza aizsardzības apliecību. Pirmo aizsardzības apliecību par bungusitdzirnavu (viens no trieciendzirnavu veidiem) pārlabojumiem Patentu valde izdeva 1922. gada 15. februārī, to ieguva rīdzinieks Andrejs Golvers (1868-1946) [7]. Vinšs patenta pieteikumu Patentu valdē bija iesniedzis 1921. gada 12 . novembrī.

Ātrai izgudrojuma patenta saṇemšanai vienmēr bija un ir svarīgi pareizi noformēt pieteikumu, īpaši izgudrojuma aprakstu, lai Patentu valdes nozaru eksperts varētu atzīt jauninājumu un ieteikt Patentu valdei izsniegt patentu pieteicējām. Latvijas Republikas Patentu valde pirmos trīs patentus izsniedza 1922. gadā. Pirmos divus patentus saṇēma 


\begin{tabular}{|c|c|c|c|c|c|c|c|c|c|c|c|c|c|c|c|c|}
\hline 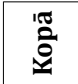 & స్. & & $m$ & ํำ & & 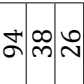 & i. $\rightarrow 0$ & 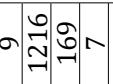 & $A \sim \sim$ & & $-\stackrel{\ln }{2} \underset{+}{\infty} \sigma$ & $-\rightarrow$ & 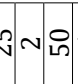 & 5 & & 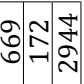 \\
\hline 용 & $\wedge$ & & & & & $\forall m$ & & $\stackrel{0}{\neq}=$ & & & $-m \sim n-$ & & $\sim 0$ & L & & 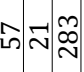 \\
\hline $\begin{array}{l}\stackrel{\text { m }}{\sigma} \\
\sim\end{array}$ & 0 & & & & & $m \sim \sim-1$ & & $\begin{array}{lll}-1 & 0\end{array}$ & & & $-\rightarrow \mid$ & & N & $\sim$ & & $\infty \infty$ \\
\hline $\begin{array}{l}\stackrel{m}{m} \\
\stackrel{\sim}{\sim}\end{array}$ & -1 & & & $-m$ & & $0 \sim \neg-$ & & శ్ర 0 N & & & $\nabla$ & $\sim$ & 0 & N & & $\approx \sim \infty \underset{\sim}{\sim}$ \\
\hline$\stackrel{\hat{m}}{\sigma}$ & $m$ & & & $m$ & & v & & 스을 & & & $-N$ & is & & N & & ㄱำ \\
\hline $\begin{array}{l}\stackrel{m}{n} \\
\stackrel{-}{\sim}\end{array}$ & $\wedge$ & & -1 & & & 6 & & 니 $\infty$ & -1 & & $-m|m|$ & -1 & & & & $\neg+\underset{\exists}{ت}$ \\
\hline$\stackrel{\text { ñ }}{\stackrel{2}{\sim}}$ & is & & $m$ & $\sim$ & & $m$ & & 이 & & & $\sim 0$ & & $m$ & $m$ & & $\vec{m} \wedge \stackrel{\sim}{\Omega}$ \\
\hline ڤે & $m$ & & & $-N$ & & เก) $N$ & & र + & -1 & & $N m$ & $m$ & $N$ & - & & 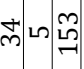 \\
\hline$\stackrel{m}{m}$ & $\sim$ & & & $N$ & & $\approx 0 \mathrm{~m}$ & & 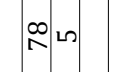 & & & $m \mid-1$ & $\sim$ & -1 & is & & ริ๐ \\
\hline$\underset{\sim}{\sim}$ & 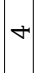 & & $N$ & $\nabla$ & & $m \rightarrow-1$ & & 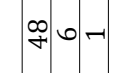 & & & $-|N|-$ & $\sim$ & $v \mid c$ & เ & & $\stackrel{m}{\infty} \infty \underset{\sim}{\sim}$ \\
\hline $\overrightarrow{\widetilde{\sigma}}$ & ㅇ & & & ما & & $\sim \sim \neg$ & & 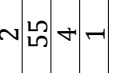 & & & $\sim m-1$ & -1 & $m$ & เ & & શֶ) \\
\hline 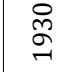 & N & & & D $\sim \sim \Omega$ & & $\neg \sim N$ & & $\nexists \approx$ & & & $\sim\llcorner\cap-1$ & $-r m$ & $N$ & $m$ & & ma \\
\hline$\stackrel{\text { స్ }}{\text { ন }}$ & $\Rightarrow$ & & & $\sim \sim m$ & & $\rightarrow \quad N$ & & $\sim \underset{\sim}{\infty}$ & & & -1 & & $m$ & $\sim$ & & 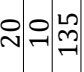 \\
\hline 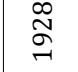 & $\exists$ & & & & & & & & & & $m m \sim$ & $m$ & $N$ & $+\sigma$ & & \\
\hline$\stackrel{\widehat{\sigma}}{\sigma}$ & $\Rightarrow$ & & & $N+$ & & $m \sim$ & & $-\& \approx-1$ & & & $m-1$ & & N & $m$ & & $\stackrel{\sim}{\sim} \underset{\sim}{\infty}$ \\
\hline$\underset{\sim}{\sigma}$ & $m$ & & & o- & & $\infty \mathrm{m} \backsim \Omega$ & & $-\infty$ & & & $m-1$ & $\sim$ & $m$ & & & $\stackrel{\infty}{\sim} \underset{\sim}{\infty} \stackrel{\infty}{\infty}$ \\
\hline$\stackrel{\stackrel{n}{\sigma}}{\sigma}$ & เก & & & & & $+\sim$ & & ำ & & & N & & & $N$ & & 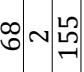 \\
\hline$\underset{\sim}{\stackrel{్}{\sigma}}$ & $\infty$ & & & $N \mid$ & & $\stackrel{1}{\sim}$ 이 & & เำก & n & -1 & $\sim N$ & -1 & $4 \quad$ เ & 0 & & $\stackrel{m}{\rightarrow} \underset{\sim}{\stackrel{\infty}{=}}$ \\
\hline$\underset{\sim}{\stackrel{\sim}{\sim}}$ & L & & & $m \mid r$ & & & & ำ & & & เก) & & $m$ & -1 & & 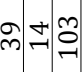 \\
\hline$\underset{\sim}{\sim}$ & & & & & & & & & & & & & & & & \\
\hline 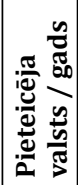 & $\overrightarrow{<}$ & 爱: & : & م| & : & : & $\tilde{a}: \frac{\pi}{3}$ & 芴: & 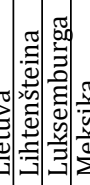 & 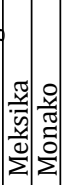 & : & م่ & 我我: & : & : & 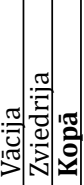 \\
\hline
\end{tabular}


ārzemnieki - Techno-Chemical Laboratories Ltd. no Lielbritānijas un Richard Klinger GmbH no Vācijas, trešo - Jānis Minuss (?-?) no Rīgas par pārvietojamo istabas krāsni ar regulējamu sildīta gaisa ieplūšanu krāsnī [8]. 1923. gadā Latvijas izgudrotāji saṇēma 20 patentu, vinu vidū jau iepriekš minētais Andrejs Golvers, kurš 24. jūlijā saṇēma patentu ar 28. numuru [9], kā arī kādreizējais RPI students Jēkabs Pilsātnieks, kurš 1923. gadā sanēma divus patentus, bet kopā sanēmis septinus.

Likumdošana vairākkārt mainījās - 1922. gada 17. maijā, 1925. gada 19. martā. 1925. gadā pien,emts arī Likums par izgudrojumu, modeḷu, fabrikas zīmējumu un preču nozīmju aizsardzību izstādēs.

Aktīvākie izgudrotāji nolēma apvienoties biedrībā - 1923. gada 14. novembrī Rìgas apgabaltiesas Reǵistrācijas nodaḷa paziṇoja, ka Rīgā registrēta «Latvijas Izgudrotāju biedrība» [10]. Tās priekšsēdētājs bija Jēkabs Pilsātnieks. Biedrība aktīvi piedalījās starptautiskās zemkopības un rūpniecības izstādēs, prezentējot Latvijas izgudrojumus un popularizējot ārvalstu izgudrotāju veikumu. Īpaši aktīva biedrības darbība bija Rīgā. Izgudrotāju biedrības biedri savus izgudrojumus reklamēja izstādēs, piemēram, 6. Rīgas izstādē 1926. gada vasarā, kurā tika demonstrēti tādi jaunizgudrojumi kā viensliežu dzelzcel̦š, tvaika katla ūdens līmeṇa rādītājs u. c. [11]. Latvijas Izgudrotāju biedrība pastāvēja līdz 1936. gada 9. novembrim [12].

Latvijas Izgudrotāju biedrībā biedru nebija daudz - izgudrotāji savus izgudrojumus ieviesa ikdienas darbā bez jebkādas reǵistrācijas. Tikai retais no Latvijas izgudrotājiem uzdrošinājās iesniegt patenta pieteikumu. Starpkaru laikā Latvijā katru gadu pieteica ap 350 dažādu izgudrojumu. Izgudrojumu patentu bija izsniegts krietni mazāk. Lielāko izgudrojumu pieteikumu skaitu veidoja ārzemnieki. No Latvijas izgudrotājiem visvairāk pieteikumu Patentu valdē iesniedza amatnieki un lauksaimnieki [13].

\section{Racionalizatoru darbība starpkaru un Otrā pasaules kara laikā}

Līdzās izgudrotājiem darbojās arī racionalizatori, kuri centās ražošanas norisi vai produkcijas ražošanu padarīt lētāku, lietderīgāku, vienkāršāku. Racionalizācijas mērksis bija ar minimāliem līdzekḷiem gūt maksimālus panākumus. Racionalizatoru darbības popularizēšanai un paveiktā izvērtēšanai 1928. gada rudenī Rīgā sarīkoja 1. darba racionalizācijas izstādi, kuras iniciators un organizētājs bija lauksaimniecības un biškopības jautājumu speciālists Fricis Galenieks (1896-1969), RPI absolventa (1917) Paula Galenieka (1891-1962) brālis [14]. 1928. gada beigās lauksaimniecības labierīcību un darba racionalizācijas izstādi 
sarīkoja Latvijas Lauksaimniecības centrālbiedrība. Šāda veida izstādes tika rīkotas arī turpmākajos gados, un par racionalizāciju runāja dažādu nozaru speciālisti, smel̦oties pieredzi no ārzemju racionalizatoriem. Racionalizācijas problēmām pievērsās arī inženieri. Piemēram, RPI absolvents (1915), LU mācībspēks Herberts Pestmalis (1891-1962) sarakstīja brošūru «Darba racionalizācija: noteikumi darba ražības pacelšanai darbnīcās, birojos un darba grupās» (1930) [15]. 1938. gadā žurnāla «Ekonomists» 23. numurā tika publicēts RPI absolventa (1901), Latvijas Universitātes profesora Eduarda Ramaña (1874-1944) raksts «Racionalizācijas vēsturiskā attīstīšanās», kas izdots arī atsevišķā izdevumā [16]. Arī otrs E. Ramaṇa raksts «Būvniecība Latvijā un tās racionalizācijas iespējas» publicēts žurnālā «Ekonomists» un izdots atsevišķā izdevumā (1939) [17].

1938. gada 12. decembrī Valsts un Ministru prezidents Kārlis Ulmanis izsludināja likumu par saimnieciskās racionalizācijas institūtu, paredzot, ka tas pētīs visus ar ražošanu saistītos jautājumus. Institūtu nodibināja Finanšu ministrijas paspārnē, «lai pētītu visus uz ražošanu attiecošos jautājumus; lai uzlabotu darba iekārtu un metodes, kā arī paceltu darba ražību rūpniecībā, amatniecībā, tirdzniecībā, lauksaimniecībā un celtniecībā; lai ievestu ražojumu standartu un it īpaši lai paceltu ražojumu kvalitāti; lai pazeminātu pašizmaksu, panāktu saimniecisku ietaupījumu, lietderīgi sadalītu darba rokas un novērstu izšksērdību materiālos un enerǵijā» [18].

Likumā bija teikts, ka minēto «mērķu sasniegšanai institūts:

1) izdara pētījumus atsevišķos uzṇēmumos, saimniecībās vai īpašās iestādēs, vai uzṇēmumu un saimniecību grupās par vēlamiem pārkārtojumiem darbu un iekārtas mehanizēšanā un ražošanas pan̄ēmienu vienkāršošanā;

2) pēta darba spēka pārvietošanos un sadalīšanos;

3) pēta iespējas uzṇēmumu administratīvās organizācijas uzlabošanai;

4) pēta iespējas standartizēt ražojumus pēc to kvalitātes, veida un izmēriem;

5) izstrādā uz savākto materiālu pamata priekšlikumus atsevišķu ražošanas nozaru vai uzṇēmumu mehāniskās un administratīvās darba iekārtas racionalizēšanai;

6) sekmē piemērota darba spēka komplektēšanu, izlasi un apmācību;

7) sniedz padomus racionalizācijas, standartizācijas un darba organizācijas jautājumos» [18]. 
Par Racionalizācijas institūta direktoru tika iecelts Latvijas Universitātes (LU) profesors Aleksandrs Delvigs (1891-1975). Lai gan veiksmīgi iesākto institūta darbu pārtrauca valsts varas mainna 1940. gada 17. jūnijā, pusotra gada laikā institūts izdeva 216 dažādus standartus. 1940. gada rudenī institūtu slēdza [18].

Otrā pasaules kara laikā, 1942. gada jūnijā, Racionalizācijas institūtu atjaunoja. Institūts noorganizēja divas izstādes: 1942. gada 1. jūlijā «Latvijas saimniecība karā» un 1942.-1943. gadā - cel̦ojošo skati «Saimnieko pareizi» [19]. Īsajā darbības laikā institūts paspēja sagatavot iespiešanai grāmatu «Krāsnis un pareiza kurināšana» (1943). Grāmatas sagatavošanā piedalījās RPI absolvents (1916), Universitātes Rīgā (Latvijas Universitātes nosaukums Otrā pasaules kara laikā (1942-1944)) profesors koksnes k̦īmiksis Arvīds Kalniṇš (1894-1981) [20]. Plānotā otrā grāmata «Lauksaimnieka darbnīca» netika izdota. Racionalizācijas institūtu atjaunoja vācu okupācijas varas iestādes, kara beigās, atkal mainoties varām, 1944. gada vasarā tas darbību izbeidza. Institūta direktors A. Delvigs devās bēglu gaitās un Latvijā vairs neatgriezās.

\section{Izgudrotājdarbība pēc Otrā pasaules kara}

Pēc Otrā pasaules kara, kad Latvija zaudēja valstisko neatkarību un bija PSRS daḷa, racionalizācijas un jaunievedumu procesi turpinājās. Par racionalizāciju un izgudrojumu ieviešanu Latvijas uzṇēmumos rakstīja prese un tika izdotas grāmatas, kas saglabājušās Latvijas Nacionālajā bibliotēkā. 20. gadsimta 40. gadu beigās un 50. gadu sākumā notika izgudrotāju un racionalizatoru republikas mēroga kongresi, semināri, sapulces un konferences. 1949. gada maija beigās notika pirmā republikas mēroga izgudrotāju un racionalizatoru konference [21]. 1956. gadā Maskavā tiek atjaunots Vissavienības izgudrotāju žurnāls, tiesa ar citu nosaukumu - žurnāla «Изобретатель» («Izgudrotājs»; 1929-1938) darbu turpināja «Изобретательство в СССР» («Izgudrotājdarbība PSRS»; 1956-1958), no 1958. gada - «Изобретатель и рационализатор» («Izgudrotājs un Racionalizators»). To līdz 1990. gadam izdeva Izgudrojumu un atklājumu lietu komiteja PSRS Ministru padomes paspārnē, un tas bija un ir lasāms arī Latvijā.

1958. gada 17. janvārī, 20 gadu pēc Vissavienības Izgudrotāju biedrības (1932-1938) likvidācijas, ar PSRS Vissavienības Arodbiedrību Centrālās padomes Prezidija lēmumu tika atjaunota Vissavienības Izgudrotāju biedrība ar nosaukumu Vissavienības Izgudrotāju un racionalizatoru biedrība (VIRB). PSRS tika dibinātas republikāniskās VIRB padomes. Vissavienības Izgudrotāju un racionalizatoru biedrības Latvijas republikāniskā padome strādāja no 1958. gada 27. februāra līdz 
1991. gada 27. augustam [22]. Vissavienības Izgudrotāju un racionalizatoru biedrības pirmais kongress notika 1959. gadā. Pēc kongresa sāka veidoties pirmorganizācijas, novatoru klubi, biroji. Piemēram, pirmo VIRB pirmorganizāciju Rīgas rajonā noorganizēja 1960. gadā Siguldas zinātniskās pētniecības saimniecībā. 1962. gadā Rìgas rajona kultūras namā noorganizēja Rīgas rajona Novatoru klubu un izveidoja Rīgas rajona VIRB padomi. Sākumā VIRB padomi izveidoja tikai lauksaimniecības uzṇēmumiem, vēlāk to apvienoja ar rūpniecības uzñēmumiem, taču kopš 1967. gada tā atkal sadalījās [23]. Tādos apstākḷos 1967. gadā tika nodibināta arī RPI VIRB pirmorganizācija, kurā apvienojās 130 Elektroenerǵētikas, Mehānikas un mašīnbūves, Ķīmijas un citu fakultāšu katedru un laboratoriju speciālisti. 1966. gadā viṇi iesniedza ap simts izgudrojumu pieteikumu, pusei no tiem bija saṇemti pozitīvi atzinumi $[24,25]$. Notika RPI VIRB pirmorganizācijas konferences.

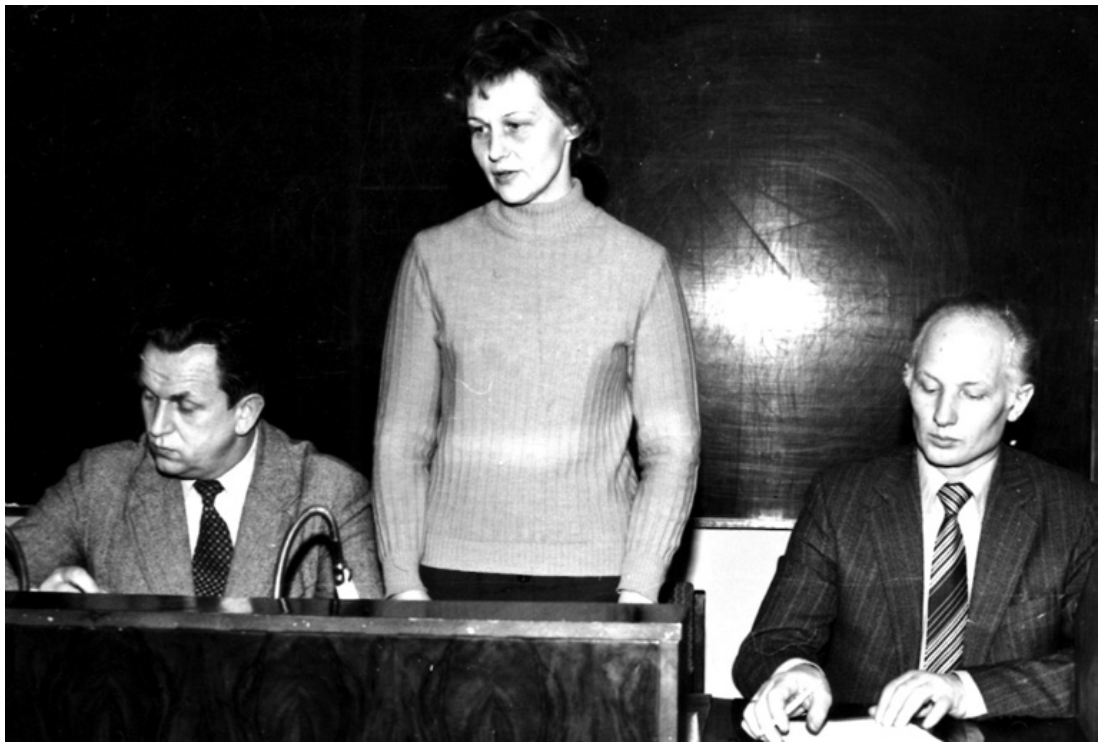

3. attēls. RPI VIRB pirmorganizācijas konference. No kreisās: docents Jānis Greivulis (1938-2010), Patentu nodalas vadītāja Māra Baltvilka, docents Viktors Mironovs (1978).

Bija arī Baltijas republiku tikšanās, piemēram, starprepublikāniskā apspriede par lauku racionalizatoru un izgudrotāju darbu Lietuvas PSR, Latvijas PSR, Igaunijas PSR un Baltkrievijas PSR notika 1968. gada augustā Viḷnā. No 1959. līdz 1969. gadam VIRB biedru skaits Latvijā palielinājās vairāk nekā četrkārtīgi. 1950. gadā Latvijas racionalizatori iesniedza vairāk nekā 7000 priekšlikumu, kuru ekonomiskais efekts bija 4,6 miljoni rubl̦u, 1969. gadā - jau vairāk nekā 51 tūkstoti priekšlikumu ar 34 miljonu rubl̦u ekonomisko efektu [26, 27].

1963. gada 27. septembrī notika Pirmais Latvijas izgudrotāju un racionalizatoru kongress. Tajā piedalījās 250 izgudrotāji un 
racionalizatori no gandrīz visiem Latvijas republikas rūpniecības, celtniecības, transporta un sakaru uzñēmumiem. Pārskata referātu par VIRB Latvijas republikāniskas padomes darbu nolasīja tās priekšsēdētājs Gunārs Rotbergs (1928-2014). Togad Latvijas izgudrotāju un racionalizatoru vidū bija apzināti 28 tūkstoši tehniskās jaunrades darbinieku (tajā skaitā 15 tūkstoši jauno racionalizatoru). Četrarpus gados, līdz kongresam 1963. gadā, ieviesti ražošanā 767 izgudrojumi un gandrīz 150000 racionalizācijas priekšlikumu, kas l̦āva Latvijai ieekonomēt 90 miljonu rubḷu [28]. 1970. gada 20. augustā Latvijas Tautas saimniecības sasniegumu izstādē Mežaparkā, Rīgā, atklāja ekspozīciju «Latvijas PSR izgudrotāju sasniegumi».

VIRB izdotā žurnāla «Изобретатель и рационализатор» («Izgudrotājs un Racionalizators») tirāža 1972. gadā sasniedza 400 tūkstošus eksemplāru. Katrā numurā tika publicēti vairāk nekā simts visdažādāko tehnisko jauninājumu. Ar PSRS Augstākās Padomes Prezidija 1979. gada 24. janvāra pavēli tika iedibināti ikgadēji svētki - Vissavienības Izgudrotāju un racionalizatoru diena, ko vērienīgi atzīmēja jūnija pēdējā sestdienā. Sākot no 1979. gada 30. jūnija, šo dienu atzīmēja arī Latvijā. Līdz šim datumam 1979. gadā racionalizācijas priekšlikumus bija iesnieguši 59500 autori, gada laikā bija ieviesti 62 tūkstoši racionalizācijas priekšlikumu un tūkstotis izgudrojumu, saṇemtas 867 autorapliecības par dažādiem izgudrojumiem. Ekonomija sasniedza 83,8 miljonu rublıu gadā [29].

Daudzu studentu pētījumu rezultāti atbilda izgudrojumu vai racionalizācijas priekšlikumu līmenim, tāpēc 1981. gada decembrī RPI sarīkoja studentu izgudrotāju un racionalizatoru pirmo salidojumu. Tajā aktīvākie studenti izgudrotāji un racionalizatori saṇēma VIRB Latvijas republikāniskās padomes un RPI Goda rakstus [30].

Racionalizatorus un izgudrotājus atbalstīja materiāli un stimulēja morāli. PSRS republikās 1959.-1961. gadā tika pien,emti likumdevēju akti par Goda nosaukumu «Nopelniem bagātais izgudrotājs» un «Nopelniem bagātais racionalizators» iedibināšanu. Krūšu zīmi «PSRS Izgudrotājs» izveidoja 1974. gada 12. decembrī, sadarbojoties PSRS Ministru Padomes Valsts komitejai izgudrojumu un atklājumu lietās un Vissavienības Izgudrotāju un racionalizatoru biedrībai, n,emot vērā PSRS Ministru Padomes un Padomju Savienības Komunistiskās partijas Centrālkomitejas 1973. gada 20. augusta rīkojumu Nr. 575. Šo krūšu zīmi PSRS izsniedza katram izgudrojuma autoram un līdzautoram ar pirmo autora apliecību, registrētu PSRS Valsts izgudrojumu reǵistrā pēc 1973. gada, ja apstiprinājās, ka izgudrojumu izmanto tautsaimniecībā. Ar šo krūšu zīmi apbalvoti daudzi RPI izgudrotāji, viṇu vidū arī tagadējais RTU rektors akadēmiksis Leonīds Ribickis. 
Atpazīstamību 20. gadsimta 70. un 80. gados ieguva apbalvojumi, ko piešksīra izgudrotājiem un racionalizatoriem par īpašiem nopelniem krūšu nozìmes ar uzrakstiem krievu valodā «Лауреат конкурса ВОИР» («VIRB konkursa laureāts»), «За активную работу в ВОИР» («Par aktīvu darbu VIRB»), «Наставник ВОНР» («VIRB darbaudzinātājs»), «Отличник изобретательства и рационализации ВОИР» («VIRB izgudrotājdarbības un racionalizācijas teicamnieks»), «Отличникорганизатор технического творчества ВОИР» («VIRB tehniskās jaunrades teicamnieks-organizators») un citi.

Gandrīz katrā kolektīvā vai padomju saimniecībā bija VIRB pirmorganizācija. Citas darbojās aktīvāk, citas - pasīvāk. 20. gadsimta 80. gadu vidū raksta autoram izdevās aktivizēt šādas organizācijas darbību sovhozā «Eglaine» Daugavpils rajonā. Rezerves dal̦u deficīta apstāklos šoferiem, traktoristiem, kombainieriem, metinātājiem, virpotājiem un mehāniḳiem pastāvīgi nācās izdomāt jaunus tehniskus risinājumus dažādām problēmām. Autors, būdams lauksaimniecības tehnikas ekspluatācijas inženieris, remontdarbnīcas, autogarāžas vadītājs, vēlāk arī saimniecības galvenais inženieris, atbalstīja racionalizācijas darbību, izstrādāja racionalizācijas priekšlikumus pats, kā arī palīdzēja citiem tos noformēt un uzrakstīt iesniegumus naudas atlīdzības saṇemšanai par jaunievedumu ieviešanu ražošanā. Latvijas rajonos notika sociālistiskās sacensības par labākā racionalizatora un izgudrotāja nosaukumiem.

Ar izgudrotājdarbību nodarbojās ne tikai studenti, bet arī skolēni. 20. gadsimta 80. gados Zemgales vidusskolā (Daugavpils rajonā) autoram izdevās izveidot VIRB pirmorganizāciju, kurā 9. un 10. klašu skolēni iepazinās ar novatorisma un izgudrošanas pamatiem, konstruējot mazgabarīta lauksaimniecības tehniku un dažādas ietaises, kas uzlaboja traktoru un auto būves apguvi [31]. Par mācību procesā izstrādātajiem un ražošanā ieviestiem jauninājumiem skolniekiem tika izsniegta «Apliecība par racionalizācijas priekšlikumu» [32]. Minētās vidusskolas skolēni novatori bija labākie Latvijā kravas auto vadīšanā, praktiskos un teorētiskos jautājumos, bet Vissavienības jauno arāju konkursā - pat visā Padomju Savienībā. Raksta autors, toreiz - 16 gadu vecs Zemgales vidusskolas skolēns - 1977. gadā ar PSRS Augstākās Padomes Prezidija pavēli tika apbalvots ar medal̦u «Par priekšzīmīgu darbu». Tas bija skolotāja novatora Romualda Jaunzema nopelns [33].

Par diplomēto un topošo inženieru sasniegumiem, sagaidot Latvijas izgudrotāju un racionalizatoru 6. kongresu, uzzinām no Latvijas PSR Nopelniem bagātā izgudrotāja, RPI VIRB padomes priekšsēdētāja docenta Viktora Mironova 1983. gadā februārī laikrakstā «Rīgas Balss» publicētā raksta «Nodoties jaunradei». Tajā lasāms, ka RPI novatori 1982. gadā Vissavienības Patentu ekspertīzes institūtam iesniedza 215 izgudrojumu pieteikumus, saṇēma 152 autoru apliecības, noformēti 
118 racionalizācijas priekšlikumi. Pēc PSRS Augstākās un vidējās speciālās izglītības ministrijas sistēmas izgudrotāju un racionalizatoru darba skates rezultātiem RPI ieguva trešo vietu. Labākās bija Automātiskās elektropiedziṇas un Automatizēto elektrisko sistēmu katedras. Toreiz labākais RPI izgudrotājs bija vecākais pasniedzējs Leonīds Ribickis, patlaban - profesors, RTU rektors, kurš arī tagad aktīvi iesaistās izgudrotājdarbībā un atbalsta Latvijas izgudrotājdarbības kustību. Lielu atbalstu VIRB RPI pirmorganizācija saṇēma no Mehānikas un mašīnbūves fakultātes (dekāns Jānis Ozoliṇš) un Patentu nodaḷas (vadītāja Māra Baltvilka). VIRB RPI pirmorganizācijas biedru skaits pārsniedza pusotru tūkstoti, notika vairāki institūta studentu izgudrotāju salidojumi [34].

No 1960. līdz 1989. gadam tika izdots Latvijas PSR Ministru Padomes Zinātniski tehniskās komitejas, Republikas tautsaimniecības padomes un LPSR Zinātniski tehnisko biedrību padomes ilustrēts populārs zinātniski tehnisks žurnāls "Zinātne un Tehnika», kas tika izdots arī krievu valodā. No 1990. līdz 1991. gadam iznāca sabiedriski politisks un zinātniski populārs žurnāls «Zinātne un Mēs», kura tirāža sasniedza pat 60000 eksemplāru mēnesī.

No 1963. līdz 1988. gadam Latvijā notika septiṇi Latvijas izgudrotāju un racionalizatoru kongresi. Šajā laikā biedru skaits, sasniedzot 180000 , palielinājās 6,4 reizes. Piemēram, 1983.-1988. gadā Latvijā ražošanā tika ieviesti 440 izgudrojumi un 300000 racionalizācijas priekšlikumi, kas ḷāva ietaupìt 585 miljonu rubḷu. To izstrādāšanā piedalījās 57000 autoru [35]. Šajos gados strauji attīstijjās augstskolu, rajonu un republikāniskās izstādes. Piemēram, 1966. gadā tika sarīkota RPI mācībspēku, aspirantu un zinātnisko laboratoriju līdzstrādnieku izgudrojumu skate [36], rajonos un pilsētas novatoru klubi organizēja jauninājumu skates, Mežaparkā tika eksponēti Latvijas PSR izgudrotāju sasniegumi. Jāatzīmē Latvijas Lauksaimniecības mehanizācijas un elektrifikācijas zinātniskās pētniecības institūta nopelnus izgudrojumu un racionalizācijas priekšlikumu izstādes «Novators» organizācijā, kas no 1971. līdz 1995. gadam notika Rīgas rajona Ulbrokā un kḷuva par lielāko Latvijas jauninājumu ekspozīciju Latvijā.

\section{Izgudrotāju biedrību darbība atjaunotajā Latvijas Republikā}

Līdz ar Latvijas Republikas valstiskā statusa atjaunošanu 20. gadsimta 90. gadu sākumā mainījās arī sabiedrisko organizāciju tiesiskās formas. VIRB Latvijas republikāniskā padome kḷuva par Latvijas Izgudrotāju un racionalizatoru biedrību (27.08.1991-22.03.1993), pēc tam par Latvijas Izgudrotāju biedrību [22]. 
No 1993. gada 22. marta līdz 2007. gada 7. februārim sabiedriskajai organizācijai «Latvijas Izgudrotāju biedrība» juridiskā adrese bija Rīgā, Šḳūṇu ielā 17. Tās darbības mērḳi bija:

1) kopā ar valsts, saimnieciskajām un citām sabiedriskajām organizācijām risināt jautājumus, kas skar Latvijas Izgudrotāju biedrības biedru un tās organizāciju likumīgās tiesības un intereses;

2) propagandēt izgudrotāju un pašdarbības autoru sasniegumus, biedrības darbību, organizēt konkursus un citus masu pasākumus tehniskās jaunrades attīstības interesēs;

3) veikt ražošanas, saimniecisko un ārējo ekonomisko darbību, lai izveidotu savu materiāli tehnisko bāzi kā pamatu praktiskās palīdzības sniegšanai izgudrotājiem viṇu priekšlikumu izstrādāšanā un ieviešanā;

4) organizēt biedrības kadru un aktīva, ražošanas speciālistu kvalifikācijas celšanu izgudrojumu, patentu, tehniskās jaunrades, marketinga un saimnieciskā aprēḳina jomā;

5) veikt lietišķu sadarbību ar ārzemju partneriem, delegāciju un specializēto tūristu grupu apmainu.

2005. gadā Latvijā sākās uzṇēmumu un sabiedrisko organizāciju pārreǵistrācija, lai atbrīvotos tādām, kas reāli nedarbojas. Rezultātā Izgudrotāju organizācija ar Nr. 40008000263 tika likvidēta, par to 2007. gada 7. februārī izdarīts ieraksts LR Uzṇēmumu reǵistrā.

2007. gadā 19. aprīlī un 15. jūnijā Rīgas Ekonomikas augstskolā, 21. maijā, 17. septembrī, 8. oktobrī un 29. oktobrī Latvijas Republikas Patentu valdes ēkā, Rīgā, norisinās izgudrotāju tikšanās sērija, kas vainagojās ar jaunas Latvijas Izgudrotāju biedrības dibināšanas sēdi 29. oktobrī. Tika pieṇemts lēmums par biedrības dibināšanu, tās Statūtu apspriešana un valdes vēlēšanas, ka arī preses konference.

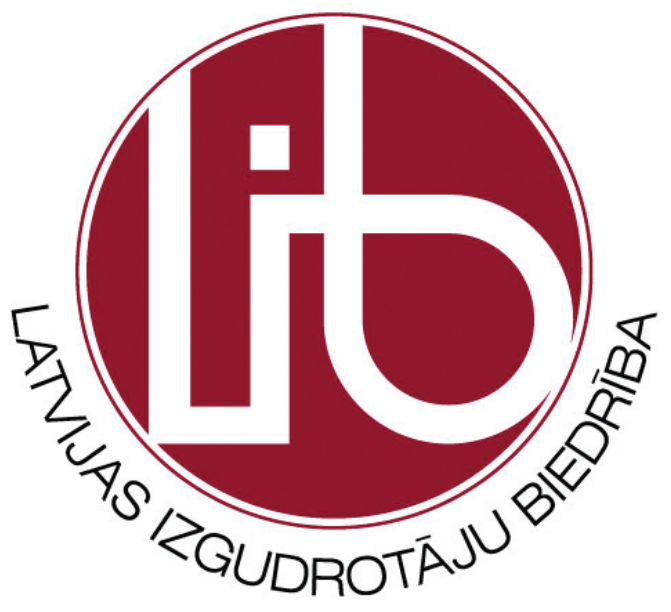

4. attēls. Latvijas Izgudrotāju biedrības logo (2009). 
Dibināšanas sēdes protokolā ierakstīts: «..vienbalsīgi tika ievēlēta biedrības valde šādā sastāvā: Aldis Eglājs (priekšsēdētājs), Elmārs Baltiņš, Normunds Lazdin,š, Rims Vaitkus, Videvuds Ārijs Lapsa un Roberts Paeglis. Tika piennemts lēmums par biedrības Statūtu iesniegšanu LR Uzṇēmumu reǵistrā. Biedrības dibinātāji ir visi klātesošie, kā arī dažādu iemeslu dēl netikušie Sergejs Matasovs un Jānis Ratenieks..». Pēc 2007. gada 12. novembrī notikušās Latvijas Izgudrotāju biedrības valdes sēdes dibināšanas dokumenti tika iesniegti LR Biedrību un nodibinājumu reǵistram, kur 2007. gada 11. decembrī tā reǵistrēta ar Nr. 40008121730, biedrības juridiskā adrese: Rīga, Āzenes iela 16/20136. Pēc biedrību reǵistra datiem, 2020. gadā Latvijas Izgudrotāju biedrība atrodas Rīgā, Prūšu ielā 1 k-1-26 [37].

Biedrības darbības mērḳi ir:

1) savstarpēji dalīties pieredzē un sniegt atbalstu biedru darbībai izgudrojumu jomā, sākot ar izgudrojumu izstrādāšanu, patentēšanas apjoma izvērtēšanu un patentu pieteikuma noformēšanu līdz izgudrojumu marketingam, realizācijai un izgudrotāju interešu aizstāvībai;

2) izstrādāt un sniegt priekšlikumus kompetentām valsts institūcijām normatīvo aktu pilnveidošanai individuālo izgudrotāju darba veicināšanai un izgudrojumu realizācijas finansiālam un tiesiskam atbalstam;

3) dot eksperta vērtējumu kompetentām valsts institūcijām par prognozējamo konkrēto izgudrojumu komerciālo vērtību un sniedzamā atbalsta apjomu;

4) dot eksperta vērtējumu potenciāliem izgudrojumu izmantotājiem un investoriem ražošanā par prognozējamo konkrēto izgudrojumu komerciālo vērtību;

5) dibināt kontaktus un sadarboties ar radniecīgām organizācijām Latvijā un ārvalstīs biedrības mērḳu realizācijai un savas darbības pilnveidošanai;

6) veicināt un popularizēt individuālo izgudrotāju darbību Latvijā;

7) veicināt potenciālo izgudrotāju izglītošanu patentzinībās;

8) piedalīties izgudrotāju darbībai veltītās izstādēs un citos pasākumos [38].

Paralēli dalībai daudzās izstādēs, semināros un konferencēs, biedrība pati arī regulāri organizē izgudrojumu izstādes un festivālus visiem interesentiem, izdodot katalogu divās valodās. Piemēram, pirmās piecas izgudrojumu izstādes, kas tika rīkotas ik gadu, sākot no 2010. gada, notika RTU galvenajā ēkā, Kal̦ ķu ielā 1 [39, 40, 41, 42, 43]. 


\section{«Суббота» noбbıаna на слёте narßuйскик uзобретатепей}
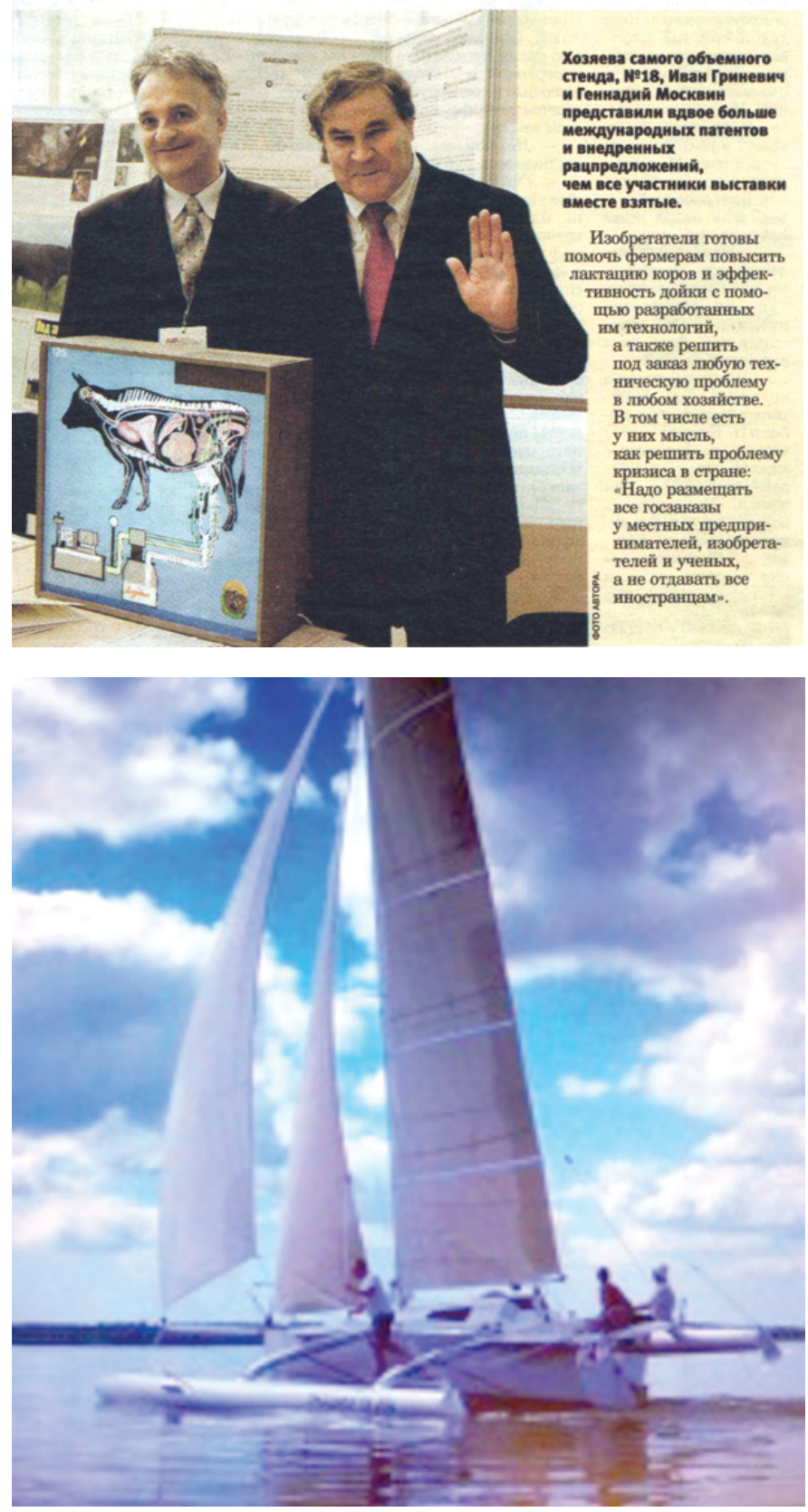

5. attēls. Latvijas izgudrojumu izstādes starpuniversitāšu stenda Nr. 18 dalībnieki Ivans Griṇevičs un RPI Aparātu būves un automatizācijas fakultātes absolvents (1974), Latvijas Lauksaimniecības universitātes Enerǵētikas institūta profesors Genādijs Moskvins (2011).
6. attēls. Latvijas Izgudrotāju biedrības priekšsēdētāja Alda Eglāja trimarāns uz zemūdens spārniem Catri 25 (2014). 
Izgudrotāju dienas un izstādes rīkošanas ideja radās 2008. gada sākumā, kad Latvijas Izgudrotāju biedrības delegācija (Aldis Eglājs, Mareks Justs, Normunds Lazdin,š, Roberts Paeglis) piedalījās 1. starptautiskās Izgudrotāju dienas festivālā Bangkokā, Taizemē. Pirmo reizi Latvijas Izgudrotāju diena tika organizēta kopā ar konferenci 2008. gada 17. decembrī Rīgas Ekonomikas augstskolā (Stockholm School of Economics in Riga). No 2012. gada pēc izgudrotāja Miervalda Rozenberga priekšlikuma izstādei tika dots nosaukums «MINOX» vārdā par godu izgudrotāja Valtera Capa 1936. gada 6. oktobrī noslēgtajam līgumam ar Valsts Elektrotehnisko fabriku par fotokameras «MINOX» ražošanu [44].

Izstādē «MINOX» notiek dažādas aktivitātes gan tehniskās jaunrades veicināšanai, gan biznesa kontaktu veidošanai, piemēram, koka auto sacensības, Stirlinga dzinēju konstruēšanas konkurss, Saules mašīnu sacensības, biznesa kontaktu programma, izglītojošas ekskursijas uz Latvijas un Igaunijas uzñēmumiem. Informāciju par intelektuālā īpašuma aizsardzību regulāri nodrošina LR Patentu valdes Patentu tehniskā bibliotēka. Piemēram, 5. starptautiskajā izgudrojumu un inovāciju izstādē «MINOX 2014» piedalījās vairāk nekā simts pieredzējuši izgudrotāji, jaunie zinātnieki, novatori, kas 51 ekspozīcijā prezentēja 68 izgudrojumus. Devin,as ekspozīcijas sagatavoja jaunieši. Izgudrojumi aptvēra plašu nozaru loku. Tika prezentēti daudzi strādājoši prototipi, model̦i un maketi. Daḷa izgudrojumu bija patentēti. Izstādes darbā piedalījās arī Kembridžas Universitātes profesors Alans Barels (Alan Barrell) no Lielbritānijas, savukārt prezentāciju par Igaunijas izgudrojumiem sniedza Igaunijas Izgudrotāju biedrības pārstāvis Leo Sīmans (Leo Siemann) [44].

6. starptautiskās izgudrojumu un inovāciju izstāde «MINOX 2016» notika 2016. gadā RTU telpās Kīipsalā. Tajā piedalījās aptuveni 150 izgudrotāju, zinātnieku, novatoru un jauniešu, kuri 82 ekspozīcijās prezentēja 92 izgudrojumus vai inovācijas. Ekspozīcijas veidoja: augstskolas un institūti - 27; individuālie izgudrotāji - 25; skolas un jaunieši - 13; uzṇēmumi un organizācijas - 10; ārvalstu izgudrotāji no Eiropas, Āzijas un Āfrikas - 7. izstādes laikā notika astoṇi pasākumi:

1) seminārs «Izgudrojumu prezentēšanas meistarklase»;

2) atzīmējot Valtera Capa līguma ar VEF 80. gadadienu, Silvijas Zakkes vadībā konference «Izgudrojumi tautsaimniecībai»;

3) biznesa kontaktu programma;

4) senioru ekspertu tīkla ikgadējā tikšanās;

5) Ziemel̦eiropas izgudrotāju biedrību sanāksme;

6) seminārs «Viḷnu enerǵijas ieguves iespējas»;

7) ekskursija pa Rīgu, apmeklējot Vilhelma Ostvalda un Paula Valdena atceres vietas;

8) izglītojoša ekskursija uz zinātnes centru «AHHAA» Igaunijā. 
Izstādes prezentācija notika Baltijas Zinātnes, tehnologisko parku un inovācijas centru asociācijas 21. starptautiskajā inovācijas konferencē «Baltic Dynamics 2016: Inovācijas un tehnologiju konverǵence - stratēǵija viedai izaugsmei» (E. Baltinnš, I. Griṇevičs), kā arī Latvijas Radio tiešajā èterā (I. Grinnevičš, A. Kiščenko, M. Rozenbergs, L. Briede) [45].

Tradicionāli visas izstādes Latvijas Izgudrotāju biedrība organizē ciešā sadarbībā ar biedrību «CONNECT Latvija». No 2016. gada izstādes rīkošanu atbalsta Latvijas Zinātṇu akadēmija (LZA), tostarp LZA viceprezidents un RTU profesors Andrejs Krasņikovs. 2018. gadā viṇš vadīja 7. starptautiskās izgudrojumu un inovāciju izstādes «MINOX 2018» organizācijas komiteju [46].

2017. gada 11. decembrī notika Latvijas Izgudrotāju biedrības svinīgā sēde par godu jaundibinātās organizācijas 10 gadu jubilejai. Latvijas izgudrotāju devumu Latvijas simtgadei augsti novērtēja LZA prezidents akadēmiķis Ojārs Spārītis, apbalvojot biedrību ar LZA prezidenta Pateicības rakstu. Latvijas Izgudrotāju biedrības svinīgajā sēdē to pasniedza LZA viceprezidents akadēmiḳis Andrejs Krasṇikovs.

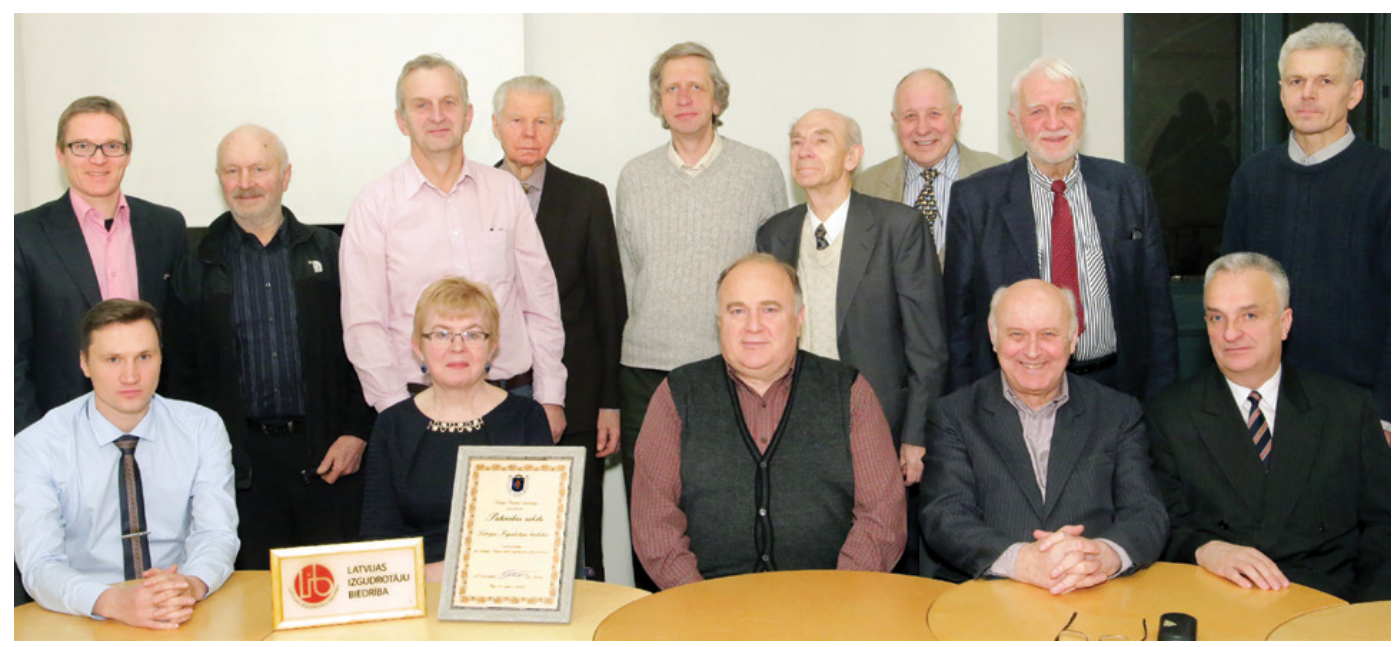

7. attēls. Latvijas Izgudrotāju biedrības biedri biedrības 10 gadu jubilejā ar LZA prezidenta Ojāra Spārīša Pateicības rakstu. 1. rindā no kreisās: Aldis Karasevs, Silvija Zakke, Andrejs Krasņikovs, Miervaldis Rozenbergs, Ivans Griṇevičs; 2. rindā no kreisās: Elmārs Baltiňš, Vilhelms Klincāns, Juris Dobrišins, Ādolfs Gertneris, Jānis Dumpis, Ernests Plarkšs, Rims Vaitkus, Videvuds Ārijs Lapsa, Zigurds Strīḳis (2017. gada 11. decembris).

Izstāde «MINOX 2018» pirmoreiz notika visos Latvijas kultūrvēsturiskajos novados: «Minox Kurzeme» - 4.-5. aprīlī Liepājā, Kr. Valdemāra ielā 4, Liepājas Universitātes Dabas un inženierzinātṇu fakultātē, «Minox 
Latgale» - 10. maijā Daugavpilī, Smilšu ielā 90, RTU Daugavpils filiālē, «Minox Vidzeme» - 2. jūnijā Cēsīs, Piebalgas ielā 3, RTU Cēsu filiālē, «Minox Zemgale» - 8. septembrī Jelgavā, Pasta salā, un «MINOX 2018» 12.-13. oktobrī Rīgā, Raiṇa bulvārī 19, LU. Piecās izstādēs savus jauninājumus demonstrēja aptuveni pusotrs simts izgudrotāju. Lielākā dal̦a eksponēto izgudrojumu publicēti izstādes katalogā latviešu un anglu valodā, kurā sniegti izgudrojumu apraksti ar ilustrācijām. Minētajā izstādē LZA eksponēja sadarbībā ar RTU izstrādātu sūknēšanas tehnoloǵiju ar lineāro peristaltisko sūkni (A. Krasņikovs, V. Ā. Lapsa) [46].

Latvijas Izgudrotāju biedrības valdes priekšsēdētājs kopš tās dibināšanas ir RPI absolvents (1962) Aldis Eglājs - SIA «Catri» un SIA «Jūras Katri» valdes priekšsēdētājs. A. Eglājam ir deviṇas PSRS autorapliecības, 29 ārzemju patenti un viens Latvijas patents. Viens no viṇa zināmākajiem izgudrojumiem ir trimarāns ar zemūdens spārniem. 2018. gada 26. aprīlī, Pasaules intelektuālā īpašuma dienā, Patentu valdes direktors Sandris Laganovskis un LZA prezidents O. Spārītis A. Eglājam pasniedza Pasaules Intelektuālā īpašuma organizācijas WIPO (World Intellectual Property Organization) medal̦u izgudrotājiem (WIPO Medal for Inventors) [47].

2019. gadā šādu medaḷu saṇēma Latvijas Izgudrotāju biedrības valdes loceklis Videvuds Ārijs Lapsa - RTU emeritētais profesors, Būvniecības inženierzinātṇu fakultātes Būvražošanas institūta vadošais pētnieks, Latvijas Betona savienības valdes loceklis. V. A. Lapsam pieder 34 PSRS autorapliecības, vin,š ir 106 izgudrojumu, septinnu ārzemju un 65 Latvijas patentu, kā arī 148 zinātnisko publikāciju autors [48].

\section{Nobeigums}

Izgudrotājdarbībai Latvijā ir sena vēsture, izgudrotāju tiesības gandrīz simts gadu aizsargā patenti. Mūsdienās patentu likumdošana pastāv vairāk nekā 120 pasaules valstīs, tostarp Latvijā, un to uzrauga Patentu valde. Patlaban Latvijas Izgudrotāju biedrībā apvienojušies vairāk nekā pussimts izgudrotāju, bet to cilvēku skaits, kuri pievērsušies izgudrotājdarbībai, ir krietni lielāks.

Latvijas izgudrotāji, tostarp inženieri, kuri studējuši RPI un RTU, radījuši daudzus izgudrojumus, kas ir nozīmīgi zinātnē, ražošanā, sadzīvē. 19. gadsimta 2. pusē un 20. gadsimta sākumā viṇi saṇēma cariskās Krievijas privilēgiju, starpkaru laikā un mūsdienās - patentus, padomju varas gados - autorapliecības. 20. gadsimta 2. pusē izgudrotāju un racionalizatoru skaits no inženieru vidus krietni palielinājās. Piemēram, RPI VIRB darbojās mācībspēki Jānis Greivulis (1938-2010), Viktors Mironovs, Videvuds Ārijs Lapsa un daudzi citi, izgudrotājdarbībā 
iesaistījās arī RPI absolventi Ādolfs Gertneris, Antons Kiščenko, Zigurds Strīksis u. c. Patlaban Latvijas Izgudrotāju biedrības valdes priekšsēdētājs ir RPI absolvents Aldis Eglājs, valdes locekḷi - RPI absolvents Miervaldis Rozenbergs, RTU absolvents Elmārs Baltiņš, RTU emeritētais profesors Videvuds Ārijs Lapsa.

Izgudrotāji turpina realizēt savas idejas dažādos projektos, bet izgudrojumi ir apskatāmi starptautiskajās un vietējās izstādēs. 2020. gada septembrī un oktobrī tās ir izgudrojumu un inovāciju izstādes «MINOX» Jelgavā un Kīipsalā Rīgā, RTU telpās.

\section{ATSAUCES}

[1] Lidzhejeva, K. V. Istorija stanovlenija i razvitija dorevolyutsionnogo patentnogo prava v Rossi. In: Vsetnik Kalmickovo instituta gumanitarnih issledovanij RAN, 2011, Nr. 2, s. 83-88.

[2] Istomin, S. Samije znamenitije izobretateli Rossii. Moskva: Veche, 2002, $478 \mathrm{~s}$.

[3] Grinevich, I. I. Vypusknik Rizhskovo politehnikuma Josif Roncheviskij osnovopolozhnik metalurgicheskoj laboratorii Tomskovo tehnologicheskovo instituta. In: Istorija i filosofija nauki v epohu peremen: sbornik nauchnih statej. T. 2. Moskva: Russkoje obshchestvo istorii i filosofii nauki, 2018, s. 70-72.

[4] Pilsatneeks, J. Elektrische Vorrichtung «Elektrograph» zum Fernhetrieb von Schreibmaschinen,Typendruck-Telegraphenapparaten und dergleichen. Rigasche Industrie-Zeitung, 1903, Nr. 18, S. 6.

[5] Bērziṇa, A. Patentu valde un izgudrotājdarbība Latvijā: 1918-1940 = The Latvian Patent Office and Inventorship in Latvia 1918-1940. Rīga: LR Patentu valde, 2018, 565 lpp.

[6] Pārgrozījumi noteikumos par izgudrojumu, model̦u un preču nozīmju aizsardzības apliecību un patentu izdošanas kārtību. Valdības Vēstnesis, 1921. gada 29. decembris, Nr. 294, 1.-2. lpp.

[7] Rūpniecības departamenta patentu valde. Valdības Vēstnesis, 1922. gada 15. aprīlis, Nr. 85, 1. lpp.

[8] Rūpniecības departamenta patentu valde. Valdības Vēstnesis, 1923. gada 7. februāris, Nr. 30, 2. lpp.

[9] Rūpniecības departamenta patentu valde. Valdības Vēstnesis, 1923. gada 28. jūlijs, Nr. 161, 1. lpp.

[10] Tiesu sludinājumi. Valdības Vēstnesis, 1923. g. 5. decembris, Nr. 271, 11. lpp.

[11] Kas redzams 6. Rīgas izstādē? Iekšlietu Ministrijas Vēstnesis, 1926. gada 19. jūnijs, Nr. 21, 3. lpp.

[12] Tiesu sludinājumi. Valdības Vēstnesis, 1936. gada 14. novembris, Nr. 260, 7. lpp.

[13] 350 izgudrojumu gadā. Brīvā Zeme, 1940. gada 23. janvāris, Nr. 18, 5. lpp. 
[14] Biroju racionalizācijas izstāde. Signāls, 1928. gada 1. oktobris, Nr. 1, 27., 28. lpp.

[15] Pestmalis, H. Darba racionalizācija: noteikumi darba ražības pacelšanai darbnīcās, birojos un darba grupās. [Rīga: b. i.], 1930, 86 lpp.

[16] Ramanis, E. Racionalizācijas vēsturiskā attīstīšanās. [Rīga: b. i.], 1938, $11 \mathrm{lpp}$.

[17] Ramanis, E. Būvniecība Latvijā un tās racionalizācijas iespējas. [Rīga: b. i.], 1939, 19 lpp.

[18] Likums par saimnieciskās racionalizācijas institūtu. Valdības Vēstnesis 1938. gada 13. decembris, Nr. 283, 1. lpp.

[19] Delvigs, A. Racionalizācijas institūta darbība. Latvju Tautsaimnieks, 1943, Nr. 3/4, 51.-56. lpp.

[20] Delvigs, A. (galv. red.). Krāsnis un pareiza kurināšana. Rīga: Saimniecības literatūras apgāds, 1943, 3. lpp.

[21] Gods un slava jaunu ceḷu meklētājiem ražošanā. Cīṇa, 1949. gada 27. maijs, Nr. 123, 1. lpp.

[22] Latvijas Izgudrotāju biedrība. Latvijas Valsts arhīva Latvijas Valsts arhīvs 1856. fonda izzina.

[23] VIRB-30. Darba Balss, 1988. gada 14. janvāris, Nr. 6, 1. lpp.

[24] Rīgas Politehniskā institūta izgudrotāji. Rīgas Balss, 1967. gada 1. februāris, Nr. 27, 7. lpp

[25] Izgudrotāji augstskolā. Cīna, 1967. gada 2. februāris, Nr. 28, 4. lpp.

[26] Lauku novatoru tikšanas. Cīna, 1968. gada 2. augusts, Nr. 179, 1. lpp.

[27] Baltijas republiku izgudrotāju tikšanās. Rĭgas Balss, 1968. gada 30. augusts, Nr. 204, 1. lpp.

[28] Gorbunova, I. «Tehniskā acs» dot tūkstošus. Padomju Jaunatne, 1963. gada 27. septembris, Nr. 190, 1. lpp.

[29] Apinīte, V. Novatoru svētki. Rīgas Balss, 1979. gada 30. jūnijs, Nr. 150, 2. lpp.

[30] Dzelzītis, E. Izgudrot - tas ir gandrīz vienkārši! Jaunais Inženieris, 1981. gada 24. decembris, Nr. 16, 4. lpp.

[31] Grinevich, I. I. Stremlenije k tvorchestvu vospityvajetsa s detstva. Narodnoje Obrozovanije, 1988, Nr. 3, s. 21-22.

[32] Grinevich, I. I. Stancii i kruzhki junih tehnikov: pervij etap priobshchenija k tehnicheskomu tvorchestvu (Daugavpils). Voprosi Izobretatelstva, 1988, Nr. 3, s. 58.

[33] Kušnere, N. Skolēnam - valdības apbalvojums. Avangards, 1977. gada 12. februārī, 2. lpp.

[34] Mironovs, V. Nodoties jaunradei. Rīgas Balss, 1983. gada 23. februāris, Nr. 44, 2. lpp.

[35] Tehniskā progresa avangardā. Darba Uzvara, 1988. gada 1. marts, Nr. 34, 1. lpp.

[36] Institūta izgudrotāji - tautas saimniecībai. Padomju Jaunatne, 1966. gada 14. decembris, Nr. 242, 1. lpp.

[37] Latvijas izgudrotāju biedrības adrese [tiešsaiste]. https://company.lursoft. lv/latvijas-izgudrotaju-biedriba/40008121730 [skatīts: 11.06.2020]. 
[38] Latvijas Izgudrotāju biedrības arhīvs.

[39] Grinevich, I. I., Moskvin, G. A. Intelligent technologies for milk production = Intellektualnije tehnologii poluchenija moloka: katalog stendovovo referata: 3ij Mezdunarodnij forum po intelektualnoj sobstvennosti «Expopriority'2011», Mezhdunarodnaja vystavka innovacij: 7-9 dekabrja 2011 goda. Moskva: CVK «Ekspocentr»; Rembate: Mezhdunarodnij selskohozajstvennij universitet, SLU, 2011, 40 str.

[40] Moskvins, G., Griṇevičs, I. Piena ražošanas tehnoloǵiju jauninājumi: 2. Latvijas izgudrojumu izstādes stenda Nr. 18 katalogs: SLU, LLU, RTU un LU izstrādātie pañēmieni, metodes un ierīces. Rembate: SLU, 2011. 36 lpp.

[41] Starptautiskā izgudrojumu izstāde «MINOX 2012»: katalogs: 2012. gada 5.-6. oktobrī: Latvijas izgudrotāju diena $2012=$ International Invention Exhibition MINOX 2012: catalogue: October 5-6, 2012: Latvian inventor's day 2012 / Latvijas izgudrotāju biedrība; biedrība «CONNECT Latvija». Rìga: RTU, 2012, 100 lpp.

[42] Latvijas Izgudrotāju biedrības un Rīgas Tehniskās universitātes pētnieku ekspozīcijas starptautiskajā izgudrojumu izstādē «MINOX 2013» / Ivana Griṇeviča redakcijā; Starptautiskā Lauksaimniecības universitāte, RTU Liepājas Zinātniskais centrs. Rembate: Liepāja, 2013, 12 lpp.

[43] 2. Starptautiskā izgudrojumu izstāde «MINOX 2013». Sastādītāji: Elmārs Baltiņš, Ivans Griṇevičs, Miervaldis Rozenbergs. Starptautiskā Lauksaimniecības universitāte, Latvijas izgudrotāju biedrība, biedrība «CONNECT Latvija», 2013, 12 lpp.

[44] Baltinšs. E., Griṇevičs, I. (sast.). 5. Starptautiskās izgudrojumu un inovāciju izstādes MINOX 2014 katalogs = Catalogue of the 5th International Invention and Innovation Exhibition MINOX 2014: 2014. gada 10.-11. oktobrī. Latvijas izgudrotāju biedrība, biedrība «CONNECT Latvija». Rīga; Rembate: Starptautiskā Lauksaimniecības universitāte, 2015, 3. lpp.

[45] Baltiṇš. E., Dumpis, J., Griṇevičs, I. (sast.). 6. starptautiskās izgudrojumu un inovāciju izstādes "MINOX 2016» katalogs = Catalogue of the 6th International Invention and Innovation Exhibition MINOX 2016: 2016. gada 7.-8. oktobrī. Rīga: Starptautiskā Lauksaimniecības universitāte, 2016, 142 lpp.

[46] Dumpis, J. (zin. red.). 7. starptautiskās izgudrojumu un inovāciju izstādes «MINOX 2018» katalogs = Catalogue of the 7th International Invention and Innovation Exhibition MINOX 2018. Rīga: Starptautiskā Lauksaimniecības universitāte, 2018, 161 lpp.

[47] Pasniegti Pasaules Intelektuālā īpašuma organizācijas apbalvojumi [tiešsaiste]. www.lrpv.gov.lv/lv/patentu-valde/aktualitates/zinas-noiestades/pasniegti-pasaules-intelektuala-ipasuma-organizacijas [skatīts: 04.04.2020].

[48] Videvudam Ārijam Lapsam piešķirta Pasaules Intelektuālā īpašuma «Medaḷa izgudrotājiem» [tiešsaiste]. www.rtu.lv/lv/universitate/masumedijiem/zinas/atvert/videvudam-arijam-lapsam-pieskirta-pasaulesintelektuala-ipasuma-medala-izgudrotajiem?highlight=videvuds+ārijs [skatìts: 04.04.2020]. 


\section{ILUSTRĀCIJU AVOTI}

1. attēls. Rigasche Industrie-Zeitung, 1903, Nr. 18, S. 6.

2. attēls. LNA LVVA 2996. f., 7. apr., 23690. 1.

3. attēls. V. Mirova personīgais arhīvs.

4. attēls. I. Grineveviča privātarhīvs.

5. attēls. Hudenko, K. Chto izobretajut v Latvii. Subbota, 2011. gada 16.-22. novembris, Nr. 46, 20.-21. lpp.

6. attēls. 5. starptautiskās izgudrojumu un inovāciju izstādes MINOX 2014 katalogs 2014. gada 10.-11. oktobris. Latvijas izgudrotāju biedrība, biedrība «CONNECT Latvija». Rīga; Rembate: Starptautiskā Lauksaimniecības universitāte, 2015, 61. lpp

7. attēls. Jān,a Brenča personīgais arhīvs.

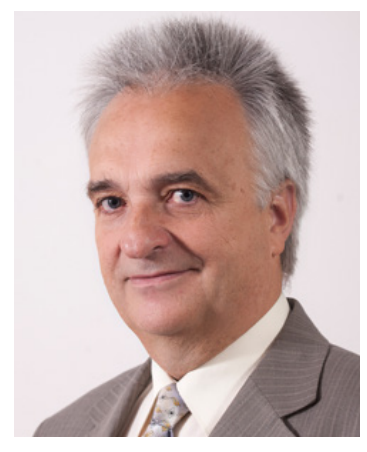

IVANS GRIN̦EVIČS, Mg. sc. ing., Mg. ing. mech., graduated from Latvia Agricultural Academy in 1984, Latvia University of Agriculture in 1992. He is a member of Latvian Society of Inventors and of Latvian Association of History of Science. He is the author and a co-author of more than three hundred publications in Latvian, Polish, Russian, English, Lithuanian and Estonian.

Adress: 11 Plavas iela, Rembate, Rembates pag.,

Keguma nov., LV-5016, Latvia

Phone: +37129258566

E-mail: biedriba_inflanty@inbox.lv

Ivans Gringevičs

\section{Development of Inventors' Activities in Latvia: Inventors' Societies, Exhibitions, Patents and the Rationalizers' Movement}

The article introduces inventors' activities and inventors' societies in Latvia in the 18th century, when it was part of tsarist Russia, until 2019. There is only one study on inventors' activities, which includes the interwar period. There are many engineers among inventors, and this study reflects the participation of students, graduates and lecturers of Riga Polytechnicum (RP), Riga Polytechnic Institute (RPI) and Riga Technical University (RTU) in inventors' activities. The research provides an insight into the history of protection of inventions, inventors' activities, international exhibitions of inventions and innovations, activities of inventors' societies.

Keywords: exhibitions of inventions, inventors' societies, Riga Polytechnic Institute, Riga Technical University. 